\title{
Uvajanje schengenskih sporazumov in standardov $v$ Republiki Sloveniji
}

UDK: 341.22/24EU

\author{
Janez Mihovec \\ Uprava kriminalistične policije Ljubljana \\ janez.mihovec@policija.si
}

\begin{abstract}
IZVLEČEK
Slovenija je tik pred koncem svoje poti med polnopravne članice schengenskega območja. Po skoraj desetletju priprav in prilagajanj kaže, da bo Slovenija z novim letom 2008 po številnih zamikih stopila v elitni klub evropskih držav brez notranjih meja in s skupno zunanjo mejo teh držav. Pri samem projektu uveljavljanja schengenskih standardov v slovenski pravni red in pri fizičnih pripravah je sodelovalo pet ministrstev in sicer za notranje zadeve, javno upravo, zunanje zadeve, pravosodje in promet. Veliko dela je bilo že opravljenega, do samega vstopa pa je treba opraviti še nekaj nalog in sicer na področju urejanja letališč, pristanišč in kadrovskih zadev.
\end{abstract}

Ključne besede: schengenski sporazumi, schengenski standardi, zunanja meja EU, notranje meje, izravnalni ukrepi

\section{Uvod}

Republika Slovenija je skoraj na koncu dolge poti, ki jo bo popeljala v elitni schengenski klub, v Evropo brez notranjih meja in s skupno zunanjo mejo. Voditelji Evropske unije so na vrhu Evropskega sveta v decembru 2006 v Helsinkih po dolgotrajnem zavlačevanju in odlašanju končno le sprejeli odločitev, da se z novim letom 2008 izvede širitev schengenskega območja z novimi članicami, ki bodo izpolnjevale vse pogoje za vstop.

Vstop v schengensko območje za Republiko Slovenijo pomeni veliko priznanje, velike pozitivne gospodarske učinke in tudi obveznosti, saj odprava notranjih meja med državami članicami, uveljavitev skupne vizne politike za državljane 
Janez Mihovec

Uvajanje schengenskih sporazumov in standardov

v Republiki Sloveniji

tretjih držav, boj proti nezakonitim migracijam, uvedba skupne zunanje meje držav članic ter uvedba komplementarnih ukrepov, ki nadomeščajo odpravo notranjih meja, pomeni tudi precejšno tveganje. Neupoštevanje schengenskih sporazumov in standardov tako lahko povzroči tudi veliko gospodarsko škodo in varnostna tveganja.

\section{Predstavitev schengenskih sporazumov}

$\mathrm{Na}$ ruševinah 2. svetovne vojne je zrasla v zahodni Evropi Evropska gospodarska skupnost. Kot ime pove, je bila najprej namenjena gospodarskemu sodelovanju, vendar pa so se stara nasprotja neverjetno hitro pozabila in prvotna gospodarska skupnost je dobivala vedno nove pristojnosti. Nastala je Evropska unija s pristojnostmi, ki so daleč presegale prvotno idejo skupnosti.

Zaradi vedno večjega sodelovanja med državami Evropske unije so meje med posameznimi državami postale ovire in tako je nastala ideja o odpravi notranjih meja med posameznimi državami članicami in vzpostavitev enotne zunanje meje držav članic. Prvi korak je bil storjen s sporazumom iz Saarbruckna iz leta 1984. S tem sporazumom je bil dogovorjen začetek postopka o postopnem zmanjšanju nadzora oseb na skupni meji med Nemčijo in Francijo. K omenjenima državama so pristopile še države Beneluksa in dne 14. junija 1985 podpisale prvi schengenski sporazum.

Nadaljni razvoj so upočasnile velike spremembe $\vee$ vzhodni Evropi konec 80-tih let in tako je bila schengenska konvencija podpisana šele dne 1. junija 1990. Formalno so jo ratificirale države članice šele 1. septembra 1993 in se je v praksi začela uporabljati 26. marca 1995.

Schengenski sporazumi so imeli namen doseči predvsem naslednje cilje:

- odprava notranjih meja med državami članicami

- uveljavitev skupne vizumske politike za državljane tretjih držav, ki omogočajo tem osebam do trimesečno prosto bivanje na področju držav članic

- boj proti nezakonitim migracijam

- uvedba skupne zunanje meje držav članic

- uvedba komplementarnih ukrepov, ki bi nadomestili pravno praznino kot posledico ukinitve notranjih meja držav članic. 


\section{Uvajanje schengenskih sporazumov in sanez Mihovec v Republiki Sloveniji}

Ideja schengenskih sporazumov je ustvaritev območja svobode, varnosti in pravice in predstavlja območje na katerem je zagotovljen prost pretok oseb, tako državljanov Evropske unije, kot tistih tujcev, ki se na območju zakonito nahajajo (Debelak in Bergelj 2002). Idejni koncept združuje $\vee$ sebi troje neločljivih elementov (svobodo, varnost, pravičnost)

Odpravljanje notranjih meja je sprva potekalo mimo institucij Evropske unije, schengenski sporazumi so bili tako vključeni v pravo Evropske unije šele $z$ Amsterdamsko pogodbo, ki je bila ratificirana $\vee$ letu 1999. Del vsebine schengenskih sporazumov je tako $v$ I. stebru (npr. skupna vizumska politika, azilna politika, imigracije), del pa $\vee$ III. stebru in sicer tisti del, ki se nanaša na policijsko sodelovanje in sodelovanje sodnih organov držav članic. Pristojnosti za sprejemanje ustreznih ukrepov za dosego omenjenega cilja so bile podeljene Svetu Evropske unije.

$V$ tem času so se $k$ schengenskim sporazumom pridruževale nove in nove države in danes $\vee$ začetku leta 2007 se schengenski sporazumi izvajajo v 15 državah. 13 držav je članic Evropske unije, 2 in sicer Norveška in Islandija pa sta članici EFTE.

Poleg omenjenih sporazumov pa je Evropska unija sprejela še celo vrsto pravnih predpisov, ki so povezani z vstopom in začasnim bivanjem državljanov tretjih držav, in sicer:

- Uredba ES 539/2001 glede obveznosti vstopnega vizuma pri prehajanju zunanje meje Evropske unije iz leta 2001

- Uredba ES 1091/2001 glede spremembe 18. člena schengenske konvencije

- Direktiva ES 2001/51 o poenotenju sankcij v zvezi s prevozniki

- Direktiva ES 2002/90 glede definicije pomoči pri nedovoljenemu vstopu in tranzitu in pri nedovoljenem bivanju iz leta 2002

- Uredba 415/2003 o izdajanju vizumov na državni meji iz leta 2003 etc. ${ }^{1}$

Republika Slovenija s članstvom v EU ni hkrati postala del schengenskega območja, ki je območje prostega gibanja oseb. Razlog za naknadno vključevanje novih članic je $v$ tem, da se na ta način predhodno zagotovijo vsi pogoji za kakovostno in popolno izvajanje schengenskega acquis-a, kar bo omogočilo dokončno ukinitev zaenkrat še obstoječe začasne schengenske zunanje meje. Republika Slovenija se je za vstop $v$ schengensko območje zavezala že s podpisom pristopne pogodbe $\vee$ Atenah leta 2003. Dejstvo, da

1 Westphal et al. 2004, stran 68 


\section{Janez Mihovec \\ Uvajanje schengenskih sporazumov in standardov \\ v Republiki Sloveniji}

Slovenija še ni del tega območja, torej ne pomeni, da omenjeni pravni red naše države ne zavezuje. Nasprotno, zavezuje jo $v$ celoti, vendar pa je njegova uporaba odložena do dne, ko bo Slovenija pristopila k schengenski konvenciji in jo $\checkmark$ celoti uvedla.

Tako je Slovenija že danes dolžna upoštevati v praksi schengenska pravila, ki so taksativno našteta $v$ Prilogi I k Pogodbi o pristopu. Tako področje varovanja meja in migracij $\vee$ Republiki Sloveniji ureja cela vrsta predpisov usklajenih z pravom EU, od katerih so najpomembnejši:

- Zakon o tujcih

- Zakon o azilu

- Zakon o varstvu osebnih podatkov

- Zakon o policiji in

- Zakon o nadzoru državne meje.

Funkcijo schengenske zunanje meje se večkrat ponazarja s funkcijo celične membrane. Meja mora tako kot membrana biti nepropustna za vse tiste državljane tretjih držav, ki ne izpolnjujejo pogojev za vstop in bivanje na schengenskem območju. Meja je enotna, kar pomeni, da so pogoji njenega prečkanja povsod, kjer poteka, enaki in natančno predeljeni. Ti pogoji, ki jih morajo izpolnjevati tudi državljani tretjih držav, ko prečkajo prihodnjo schengensko zunanjo mejo so:

- veljavna potna listina

- veljaven vizum, v kolikor gre za državljana tretje države z vizumsko obveznostjo

- dokumenti, ki dokazujejo namen vstopa in zadostna sredstva za preživljanje

- posamezniku ni prepovedan vstop

- posameznik ne predstavlja grožnje za javni red, nacionalno varnost ali mednarodne odnose katere od schengenskih držav. ${ }^{2}$

Z odpravo notranjih meja države morajo članice izvesti še dva važna ukrepa: okrepitev zunanje meje in uvedbo komplementarnih ukrepov ter na podlagi le-teh vzpostaviti razmere, ki z varnostnega vidika dopuščajo možnost začetka oblikovanja območja prostega gibanja oseb. Ukinitev notranjih meja tako ne

2 Debelak 2002, str. 77 


\section{Janez Mihovec \\ Uvajanje schengenskih sporazumov in standardov v Republiki Sloveniji}

sme povzročiti zmanjšanja varnosti, ampak mora državljanom EU zagotoviti večjo varnost. ${ }^{3}$

Oblikovanje skupne zunanje meje schengenskih držav zahteva tudi oblikovanje skupne vizumske politike. Pravno izhodišče zanjo predstavlja IV. poglavje Pogodbe o Evropski uniji, s katero je svetu EU podeljena pristojnost za sprejemanje pravil, ki na tem področju urejajo razmerje držav članic EU do tretjih držav ter njihovih državljanov. Za bivanje tujcev na schengenskem območju do 3 mesecev veljajo za države EU skupna pravila, ki določajo:

- seznam tretjih držav, katerih državljani morajo imeti vizum pri prečkanju schengenske zunanje meje, in tistih držav katerih državljani nimajo te obveznosti

- $\quad$ postopke in pogoje za izdajo vizumov držav članic

- enotni format za vizum

- pravila o enotnem vizumu. ${ }^{4}$

Schengenski sporazumi in skupna vizumska politika zahtevajo tudi informatizacijo vizumskega postopka in postopka kontrole na zunanji meji. Pomembna sta dva informacijska sistema in sicer schengenski informacijski sistem (SIS) in Vizumski informacijski sistem (VIS).

SIS zagotavlja policijskim organom dostop do baz podatkov držav članic, ki vključujejo informacije o:

- osebah, za katere je bil izrečen kazenski ukrep izgona iz države

- tujcih, ki se nahajajo na seznamu oseb, katerim je prepovedan vstop v državo

- pogrešanih osebah ali osebah, ki potrebujejo začasno policijsko zaščito

- pričah in osebah, ki so bile povabljene na zaslišanje pred pravosodnimi organi

- osebah, ki so podvržene posebnemu nadzoru ali kontroli zaradi storitve kaznivih dejanj ali ker predstavljajo grožnjo javni varnosti

- izgubljenih ali ukradenih stvareh in predmetih.

VIS zagotavlja možnost posvetovanja s centralnimi organi države članice ali EU v okviru vizumskega postopka. Namenjen je izmenjavi vizumskih podatkov, ki se nanašajo na vse vrste vizumov, ki jih definirajo Skupna konzularna navodila.

3 Debelak in Bergelj, 2002, str.1

4 Debelak in Bergelj, 2002, str.5 
Janez Mihovec

Uvajanje schengenskih sporazumov in standardov

v Republiki Sloveniji

Vsebuje naslednje podatke:

- alfanumerične znake iz vlog za izdajo vizuma

- fotografijo prosilca vizuma

- biometrične podatke, ki se nanašajo na prosilca vizuma

- skenirane dokumente in

- podatke o pomožni dokumentaciji, ki jo vizumski vlogi priloži prosilec. ${ }^{5}$

\section{Izvedbeni načrt za uveljavitev schengenskih standardov nadzora zunanje meje Evropske unije}

\subsection{Opredelitev področij za uveljavitev schengenskih standardov}

Vlada Republike Slovenije je že v maju 2001 sprejela 1. izvedbeni načrt za uveljavitev schengenskih standardov nadzora bodoče zunanje meje Evropske unije. Vsebinsko in po metodološki zasnovi predstavlja izvedbeni načrt operativni program ukrepov, ki jih mora Republika Slovenija uresničiti za popolno uveljavitev schengenskega pravnega reda in tehničnih standardov za nadzor bodoče zunanje meje Evropske unije.

$\checkmark$ maju leta 2005 je sprejela Vlada Republike Slovenije Dopolnitev izvedbenega načrta za uveljavitev schengenskih standardov nadzora zunanje meje Evropske unije za obdobje 2005-07 oziroma t. i. 2. izvedbeni načrt.

$\checkmark$ izvedbenih načrtih je opredeljen nadzor državne meje $z$ različnih vidikov: z organizacijskega, kadrovskega, izobraževalnega, informacijsko-telekomunikacijskega in finančnega. ${ }^{6}$

Že samo dolgotrajno prilagajanje in priprave Republike Slovenije na izpolnjevanje schengenskih sporazumov in standardov nam da vedeti, da gre za kompleksen proces. $\vee$ tem procesu sodelujejo številni resorji in sicer:

- Ministrstvo za notranje zadeve

- Ministrstvo za zunanje zadeve

- Ministrstvo za javno upravo, Direktorat za investicije, nepremičnine in skupne službe državne uprave

5 Debelak in Bergelj 2002, str. 5 
- Ministrstvo za finance

- Ministrstvo za promet in

- Ministrstvo za pravosodje

Tako je izvedbeni načrt sestavljen iz petih delov:

- izvedbeni del načrta Ministrstva za notranje zadeve/policije

- izvedbeni del načrta Ministrstva za javno upravo

- izvedbeni del načrta Ministrstva za zunanje zadeve

- izvedbeni del načrta Ministrstva za pravosodje

- izvedbeni del načrta Ministrstva za promet?

\subsection{Pristojnosti Ministrstva za notranje zadeve (policije) pri izpolnjevanju schengenskih standardov}

Meja z republiko Hrvaško, ki je istočasno tudi prihodnja schengenska meja, je dolga 670 kilometrov. Na tem območju bo 66 mejnih prehodov, od tega 16 mednarodnih cestnih, 8 mednarodnih železniških, 9 meddržavnih mejnih prehodov, 27 prehodov za obmejni promet ter trije mednarodni letališki mejni prehodi in 3 mednarodni pomorski mejni prehodi. Poleg mejnih prehodov pa bo treba varovati tudi zeleno in modro mejo.

Republika Slovenija je podpisala vrsto sporazumov s sosednjimi državami. Sporazumi opredeljujejo policijsko sodelovanje med sosednjimi državami.

Podpisan in ratificiran je bil Sporazum o čezmejnem policijskem sodelovanju med Republiko Slovenijo in Republiko Hrvaško. Izvedbeni akti, ki jih predvideva sporazum, so ratificirani oziroma so $v$ zaključni fazi priprave. To so protokoli o mešanih patruljah, službenem tranzitu in uradnikih za zveze ter o skupnih kontaktnih točkah in skupnih delovnih skupinah.

Slovenija je podpisala in ratificirala tudi sporazume o policijskem sodelovanju z Avstrijo, Madžarsko in Italijo.

6 Debelak 2002, str.79

7 Dopolnitev izvedbenega načrta za uveljavitev schengenskih standardov nadzora zunanje meje EU 2005-07, Vlada RS, Ljubljana, maj 2005, stran 6 
Janez Mihovec

Uvajanje schengenskih sporazumov in standardov

v Republiki Sloveniji

\subsubsection{Organizacijske spremembe v organizaciji policije}

Izvedbena načrta za uveljavitev schengenskih standardov sta opredelila organizacijo policije. Upoštevane so bile izkušnje tujih policij (predvsem nemške in avstrijske, ker sta bili obe državi partnerski državi v projektu Phare: Vzpostavitev učinkovitega sistema nadzora državne meje) ter prednosti in slabosti obstoječega koncepta slovenske policije. Ključne ugotovitve in odločitve so bile naslednje:

- Obstoječi organizacijski koncept slovenske policije je koncept enotne policije z enotnim poveljstvom za vsa področja oz. naloge policije in ne vključuje posebne mejne policije znotraj ministrstva za notranje zadeve ali znotraj policije.

- Ob uveljavitvi schengenske meje se ne vzpostavi posebna mejna policija, pač pa se obstoječi organizacijski koncept slovenske policije modificira tako, da se $v$ aktu o organizaciji in sistemizaciji delovnih mest predvidi največja možna avtonomija in specializacija skupin za mejno kontrolo na mejnih prehodih in skupin za varovanje državne meje izven mejnih prehodov.

- Zaradi pomanjkanja izkušenj pri izvajanju izravnalnih ukrepov, ki so posledica ukinitve mejne kontrole na notranjih mejah, so bile upoštevane nemške in avstrijske izkušnje, varnostna predvidevanja, posebnosti posameznih odsekov prihodnje notranje meje ter izkušnje glede organiziranosti in dela prometne policije. Ustanovijo se regionalne mobilne enote za izvajanje izravnalnih ukrepov na notranjih mejah, na državni ravni pa specializirana enota za nadzor državne meje.

- Nova organiziranost policije na področju nadzora državne meje je predvidena za prihodnjo zunanjo in notranjo schengensko mejo in sicer na treh organizacijskih ravneh: na lokalni, regionalni in državni ravni.

- Predpogoj za učinkovit nadzor državne meje je tudi stalna navzočnost kriminalistične stroke, ki se zagotovi s povečanjem števila delovnih mest kriminalistov $v$ obstoječih organizacijskih enotah.

- V obstoječih organizacijskih enotah se prav tako poveča število delovnih mest $s$ področja informatike in telekomunikacij in strokovnotehničnih delovnih mest. ${ }^{\mathbf{8}}$

8 Dopolnitev izvedbenega načrta za uveljavitev schengenskih standardov nadzora zunanje meje EU 2005-07, Vlada RS, Ljubljana, maj 2005, stran 11. 


\section{Uvajanje schengenskih sporazumov Janez Mihovec v Republiki Sloveniji}

Sedaj opravlja naloge nadzora meje republike Slovenije 35 policijskih enot. Po novi organizaciji pa bo te naloge opravljalo 43 policijskih enot. Najpomembnejše spremembe $v$ organizaciji policije na lokalni ravni so naslednje:

- Notranja organizacija kombiniranih policijskih postaj je spremenjena tako, da so bile zaradi avtonomije vodenja in potrebne specializacije vodenja in potrebne specializacije izvajanja mejno-policijskih nalog uvedene skupine za mejno kontrolo in skupine za varovanje državne meje.

- Za izvajanje nalog nadzora zunanje meje EU bosta ustanovljeni še 2 policijski postaji (PMP Rogatec in PMP Bistrica ob Sotli).

- Za izvajanje izravnalnih ukrepov ob prihodnji notranji meji in $v$ notranjosti države bo v PU Koper, PU Kranj, PU Ljubljana, PU Maribor, PU Murska Sobota in PU Nova Gorica ustanovljenih 6 postaj za izravnalne ukrepe.

- Na sedanji državni meji z Italijo, Avstrijo in Madžarsko bodo ob dokončni uveljavitvi schengenskega pravnega reda ukinjena delovna mesta za izvajanje nadzora državne meje $\vee 24$ policijskih enotah in 2 sektorjih uniformirane policije, 643 delovnih mest policista in 69 delovnih mest strokovno tehničnih delavcev pa bo prenesenih v enote na zunanji meji. ${ }^{9}$

Na regionalni in državni ravni pa so bile dosežene naslednje spremembe:

- Ustanovljena je bila specializirana enota za nadzor državne meje za območje vse države, ki deluje $v$ okviru sektorja mejne policije $v$ upravi uniformirane policije GPU, ki bo do ukinitve kontrole na notranjih mejah na notranjih mejah izvajala naloge $v$ zvezi z nadzorom državne meje na državni ravni, kasneje pa bo izvajala še izravnalne ukrepe.

- Ustanovljen je bil oddelek SIRENE za iskanje oseb, predmetov in policijsko sodelovanje $v$ okviru SIS, ki deluje v okviru sektorja za mednarodno policijsko sodelovanje $\vee$ upravi kriminalistične policije GPU.

- Sistemizirana so bila dodatna delovna mesta $\vee$ centru za forenzične preiskave, $v$ sektorju za organizirano kriminaliteto $v$ upravi kriminalistične policije in $\vee$ sektorju mejne policije $v$ upravi uniformirane policije ter $v$ uradu za informatiko in telekomunikacije GPU.

- V sektorju mejne policije, uprave uniformirane policije je bil ustanovljen oddelek za izravnalne ukrepe.

9 Dopolnitev izvedbenega načrta za uveljavitev schengenskih standardov nadzora zunanje meje EU 2005-07, Vlada RS, Ljubljana, maj 2005, stran 11. 
Janez Mihovec

Uvajanje schengenskih sporazumov in standardov

v Republiki Sloveniji

\subsubsection{Sistemizacija delovnih mest, zaposlovanje in premeščanje delavcev policije $v$ zvezi $z$ uvajanjem schengenskih standardov}

Predvideno število policistov, potrebnih za izvajanje schengenskega pravnega reda za vse tri nivoje organiziranosti policije na bodoči zunanji schengenski meji, za izravnalne ukrepe in $v$ notranjosti države izhajajočih iz schengenskega izvedbenega načrta, je 3092 delovnih mest policistov na lokalni, regionalni in državni ravni. Od tega števila je 2810 delovnih mest predvidenih na lokalni ravni.

Na lokalni ravni, na zunanji meji je trenutno sistemiziranih 1919 schengenskih delovnih mest, od katerih je zasedenih 1672 delovnih mest. To pomeni, da manjka na lokalni ravni za nadzor schengenske meje še 247 policistov. Poleg že sistemiziranih delovnih mest policist na lokalni ravni, ciljna schengenska sistemizacija predvideva še dodatnih 891 policistov. Od tega števila bo 648 delovnih mest preneseno iz prihodnje notranje meje, dodatno pa bo treba sistemizirati in zasesti še 253 delovnih mest policista na lokalni ravni. Del teh mest bo zasedenih z prerazporeditvami, del pa z zaposlitvijo novih delavcev.

Na regionalni ravni je predvidenih 168 delovnih mest. Trenutno je zasedenih 50. Nezasedena delovna mesta na regionalni ravni bo policija zasedla $s$ prerazporeditvami. Na državni ravni je predvidenih 114 schengenskih delovnih mest. Trenutno zasedenih je 73 mest, primanjkljaj se bo nadomestil z notranjimi prerazporeditvami. ${ }^{\mathbf{1 0}}$

\subsubsection{Informacijsko-telekomunikacijski sistem ter vzpostavitev in delovanje schengenskega informacijskega sistema}

V schengenskem izvedbenem načrtu, ki se izvaja, so bili predvideni naslednji informacijsko-telekomunikacijski projekti:

- infrastruktura za LAN

- pristopno omrežje

- digitalni radio

- rezervni računalniški center

- AFIS

10 Dopolnitev izvedbenega načrta za uveljavitev schengenskih standardov nadzora zunanje meje EU 2005-07, Vlada RS, Ljubljana, maj 2005, stran 14-15 
- imaging

- tehnično varovanje

- informacijska podpora SIRENE in VISION

- SISNET in SIRPIT.

Sredstva za dokončanje naštetih projektov naj bi bila zagotovljena iz schengenskega vira za investicije $v$ zunanje meje Evropske unije, kar pomeni, da bi morali ob morebitnih zamikih rokov za povezavo nacionalnega informacijskega sistema in nacionalne enote SIRENE z novim SIS ustrezno zamakniti tudi možnost črpanja omenjenih finančnih sredstev. ${ }^{11}$

\subsubsection{Tehnična oprema in objekti policijski enot za nadzor državne meje}

Ministrstvo za notranje zadeve je pripravilo spremembe pravilnika o sistemizaciji in tipizaciji materialno-tehničnih sredstev in opreme in njegova uskladitev $s$ predvideno organizacijo in sistemizacijo delovnih mest policije $\vee$ luči uvedbe schengenskih sporazumov.

Za opremo za izvajanje nalog nadzora na zunanji meji EU so bila zagotovljena sredstva Phare in s temi sredstvi je bilo nabavljena cela vrsta opreme in sicer:

- prevozna sredstva

- oprema za nadzor državne meje

- kriminalistično tehnična oprema

- posebna tehnična sredstva in oprema.

Del te opreme je še $v$ fazi nabave in sicer:

- prevozna sredstva, vključno s posebnimi vozili za izvajanje izravnalnih ukrepov t.i. schengen-avtobusi

- oprema za nadzor državne meje - optoelektronske naprave, termovizije, naprave za ugotavljanje verodostojnosti dokumentov, sredstva za pregled vozil, ipd.

- posebna tehnična sredstva in pripomočki - oprema za strojno branje registrskih tablic, helikopterji, osebna zaščitna oprema, patruljni čoln ipd.

11 Dopolnitev izvedbenega načrta za uveljavitev schengenskih standardov nadzora zunanje meje EU 2005-07, Vlada RS, Ljubljana, maj 2005, strani 19-20 
Janez Mihovec

Uvajanje schengenskih sporazumov in standardov

v Republiki Sloveniji

Izvajanje schengenskih sporazumov in standardov zahteva tudi izgradnjo in adaptacijo objektov, potrebnih za njihovo izvedbo. V skladu z izvedbenim načrtom je predvidena $v$ letih 2005-07 izgradnja 6 novogradenj in 18 adaptacij objektov $v$ vrednosti $11,453 \mathrm{mrd} \mathrm{SIT}$.

\subsubsection{Ocena stroškov uveljavitev schengenskih standardov nadzora državne meje v obdobju 2005-2006}

Skupna ocena stroškov vzpostavitve nadzora državne meje $v$ skladu $s$ schengenskimi kriteriji $v$ omenjenem obdobju znaša 48,6 milijard SIT $(202,6$ mio EUR). Predvideva se, da bo vsako leto izvajanja schengenskih sporazumov in standardov po letu vstopa stalo dodatnih 74 mio EUR.

Ocena stroškov temelji na izračunu odhodkov proračunskih sredstev po naslednjih namenih prikazanih $v$ tabeli št. 1 :

Tabela št. 1: Pregled ocene stroškov uveljavitev schengenskih standardov po namenu v SIT

\begin{tabular}{|lrcr|}
\hline Namen & \multicolumn{1}{c}{$\begin{array}{c}\text { Predlog } \\
\text { rebalansa 2005 }\end{array}$} & \multicolumn{1}{c|}{ Plan 2006 } & \multicolumn{1}{c|}{ Skupaj } \\
\hline Plače & 9.119 .580 .480 & 10.778 .618 .880 & 19.898 .199 .360 \\
Osnovna oprema & 420.734 .400 & 251.712 .000 & 672.446 .400 \\
$\begin{array}{l}\text { Izobraževanje } \\
\text { Redni materialni } \\
\text { stroški }\end{array}$ & 233.360 .160 & 472.620 .000 & 705.980 .160 \\
$\begin{array}{l}\text { Investicije } \\
\text { Skupaj ocena } \\
\text { stroškov projekta }\end{array}$ & 1.318 .276 .800 & 1.644 .904 .800 & 2.963 .181 .800 \\
\hline
\end{tabular}

Opomba: skupaj torej 215,9 mio EUR, $v$ letu 2006 je $v$ seštevku upoštevana tudi finančna obveznost, ki bo zapadla v plačilo $v$ letu 2007 in sicer za izobraževanje 45,5 mio SIT (0,2 mio EUR) in investicije 4,6 mrd SIT (19,2 mio EUR ${ }^{13}$

12 (Dopolnitev izvedbenega načrta za uveljavitev schengenskih standardov nadzora zunanje meje EU 2005-07, Vlada RS, strani 24-29, Ljubljana, maj 2005).

13 Dopolnitev izvedbenega načrta za uveljavitev schengenskih standardov nadzora zunanje meje EU 2005-07, Vlada RS, Ljubljana, maj 2005, stran 35). 


\section{Uvajanje schengenskih sporazumov in standardov v Republiki Sloveniji}

Največji delež stroškov vzpostavitve schengenske meje odpade na investicije in sicer $53,2 \%$ ter na plače $38,5 \%$, medtem ko preostali stroški pomenijo le manjši delež (osebna oprema 1,3\%, izobraževanje 1,3\% in redni materialni stroški 5,7\%).

Investicijske nabave so se do leta 2004 realizirale pretežno na podlagi podpisanih finančnih memorandumov in sicer iz sredstev Phare $v$ višini 5,2 mlrd SIT ter 6,3 mrd iz naslova lastne soudeležbe. V letih 2005 in 2006 je bilo za realizacijo investicijskih nabav predvideno izkoriščanje schengenskega sklada EU in rednih proračunskih sredstev za plačilo davka na dodano vrednost. Iz sredstev schengenskega sklada so se financirali stroški plač novo zaposlenih policistov, njihovega opremljanja z osebno opremo ter stroški izobraževanja kandidatov za policiste in usposabljanj policistov za izvajanje nalog nadzora državne meje.

Tabela št. 2: Pregled dinamike po virih financiranja v SIT

\begin{tabular}{|lrrr|}
\hline Viri financiranja & \multicolumn{1}{c}{$\begin{array}{c}\text { Predlog } \\
\text { rebalansa 2005 }\end{array}$} & \multicolumn{1}{c|}{ Plan 2006 } & \multicolumn{1}{c|}{ Skupaj } \\
\hline Proračun & 4.683 .219 .506 & 13.108 .769 .129 & 17.791 .988 .636 \\
Phare & 2.591 .008 .627 & 746.157 .000 & 3.337 .165 .627 \\
donacija & 1.614 .000 .000 & 351.300 .000 & 1.965 .300 .000 \\
lastna udeležba & 977.008 .627 & 394.857 .000 & 1.371 .865 .627 \\
Schengenski sklad & 12.057 .870 .334 & 18.394 .130 .666 & 30.452 .001 .000 \\
Proračunska sredstva & 2.000 & 150.720 .000 & 150.722 .000 \\
donacija & 1.000 & 140.400 .000 & 140.400 .000 \\
lastna udeležba & 1.000 & 10.320 .000 & 10.321 .000 \\
\hline Skupaj & 19.332 .100 .468 & 32.399 .776 .795 & 51.731 .877 .263 \\
\hline
\end{tabular}

Opomba: v letu 2006 je v seštevku upoštevana tudi finančna obveznost iz leta $2007^{\mathbf{1 4}}$

14 Dopolnitev izvedbenega načrta za uveljavitev schengenskih standardov nadzora zunanje meje EU 2005-07, Vlada RS, Ljubljana, maj 2005, stran 36. 
Janez Mihovec

Uvajanje schengenskih sporazumov in standardov

v Republiki Sloveniji

\subsection{Pristojnosti Ministrstva za javno upravo pri izpolnjevanju schengenskih standardov}

Vlada Republike Slovenije je v letu 2000 za koordinatorja vzpostavitve varnostnega, carinskega in inšpekcijskega nadzora na zunanji meji EU določila ministra za evropske zadeve in hkrati ustanovila ministrsko koordinacijo, v kateri sodelujejo še zunanji, finančni, notranji, zdravstveni, okoljski, kmetijski in prometni minister ter generalni sekretar vlade. Naloga koordinacije je, da se medresorsko uskladijo odločitve, kar bo prispevalo k boljši dinamiki realizacije projekta za vzpostavitev zunanje meje Evropske unije.

Ministrstvo za javno upravo je tako pristojno preko Direktorata za investicije, nepremičnine in skupne službe državne uprave za izgradnjo mejnih prehodov. Mejni prehodi so razdeljeni v 3 skupine in sicer:

- tisti, ki so ključnega pomena za osebni promet, prevoz blaga, živali in živil preko zunanje meje EU - 6 mejnih prehodov

- drugi mejni prehodi - 25 mejnih prehodov

- mejni prehodi za obmejne prehode po SOPS-u - 23 mejnih prehodov

Skupna potrebna sredstva za realizacijo nedokončanih projektov pri vzpostavitvi mejnih prehodov na zunanji meji znašajo 10,6 milijard SIT. Viri predvideni za izvedbo programa pa so naslednji:

- 1.5 milijarde SIT (6,25 mio EUR) evropskih nepovratnih sredstev Phare iz naslova EDIS

- 2.7 milijarde SIT (11,27 mio EUR) iz Schengenskega vira financiranja

- preostanek 6,4 milijarde SIT (26,71 mio EUR) iz integralnega proračuna RS.

\subsection{Pristojnosti Ministrstva za zunanje zadeve}

Republika Slovenija je z vstopom v EU sprejela tudi soodgovornost za zagotavljanje prostora svobode, varnosti in pravice državljanov EU. Republika Slovenija ima razvejano mrežo 43 diplomatsko konzularnih predstavništev, pooblaščenih za vizumsko poslovanje, od tega je 7 generalnih konzulatov in 36 veleposlaništev.

Uslužbenci diplomatsko konzularnih predstavništev pri vizumskem poslovanju uporabljajo določbe pravnega reda EU, ki so za nove države članice $v$ 


\section{Uvajanje schengenskih sporazumov in standardov v Republiki Sloveniji}

skladu z aktom o pristopu $v$ tem trenutku zavezujoče in določbe Skupnih konzularnih navodil $\vee$ meri, ki je predvidena za države članice, ki še ne izvajajo schengenskega pravnega reda $v$ celoti.

Vsa diplomatsko konzularna predstavništva so opremljena z vizumskim informacijskim sistemom VIZIS, ki jih povezuje z Ministrstvom za zunanje zadeve. VIZIS omogoča opravljanje vseh vizumskih postopkov, preverjanje vizumskih prosilcev, shranjevanje podatkov o odločitvah $v$ zvezi s posamezno vlogo in delo z vizumskimi nalepkami. VIZIS je tudi povezan z nekaterimi evidencami MNZ, kar omogoča posvetovanje in odločanje o izdaji vizumov. Sistem se glede na nove zahteve EU vseskozi nadgrajuje. Sistem VIZIS bo v prihodnje povezan z evropskih vizumskim informacijskim sistemom VIS ter tako postal del SIS (schengenskega informacijskega sistema), ki bo povezoval vse države članice Evropske unije.

Z vstopom $v$ schengenski režim se bodo Skupna konzularna navodila in drugi standardi vizumskega poslovanja začeli uporabljati v celoti (enotni evropski vizum), kar bo zaradi zapletenejših in dolgotrajnejših postopkov pomenilo dodatno obremenitev diplomatsko konzularnih predstavništev ter potrebo po dodatnem usposabljanju konzularnega osebja. Zaradi vse bolj zahtevnih postopkov in nalog, s katerimi se sooča MZZ, je bila v letu 2005 imenovana projektna skupina, katere naloga je koordinacija dela MZZ in sodelovanje MZZ z drugimi državnimi organi za uveljavitev schengenskih standardov pri vizumskem poslovanju.

Projektna skupina MZZ je pripravila dopolnitev obstoječega izvedbenega načrta $v$ delu, ki se nanaša na vizumske postopke in uvedbo VIS ter indikativni program za črpanje finančnih sredstev iz schengenskega vira.

\subsubsection{Kadrovske spremembe na Ministrstvu za zunanje zadeve}

Schengenski pravni red določa, da mora $v$ vsaki državi članici obstajati centralni organ, ki deluje kot kontaktna nacionalna točka za konzultacije z drugimi državami članicami. Konzultacije potekajo med centralnimi organi posamezne države članice, ki skrbijo, da se podatki posameznih vizumskih vlog posredujejo centralnim organom drugih držav članic. Za delo $v$ centralnem organu izvedbeni načrt predvideva zaposlitev 3 delavcev.

Novi vizumski postopki $v$ skladu $s$ schengenskimi standardi so zahtevnejši, dolgotrajnejši in odgovornejši. Vizumska politika nima več učinka le na 
Janez Mihovec

Uvajanje schengenskih sporazumov in standardov

v Republiki Sloveniji

državo članico, ki vizum izda, ampak na celotno Evropsko unijo. Izvedbeni načrt tako predvideva zaposlitev dodatnih 16 delavcev.

Zaradi novih nalog in povečanega obsega dela za potrebno nadgradnjo, razvoj in vzdrževanje sistema VIZIS in njegovo integracijo $v$ VIS, zaradi povečanih potreb po logistični podpori predvideva izvedbeni načrt do leta 2007 zaposlitev dodatnih 10 delavcev.

\subsubsection{Ocena stroškov}

Vse omenjene aktivnosti seveda povzročijo velike stroške, prikazane $\vee$ tabeli št. 3

Tabela št. 3 Predvideni stroški MZZ pri uvedbi schengenskih standardov v SIT

\begin{tabular}{|c|c|c|c|c|}
\hline Naloga & 2005 & 2006 & 2007 & Skupaj \\
\hline $\begin{array}{l}\text { Kadri, dodatno } \\
\text { zaposlovanje }\end{array}$ & 73.628 .930 & 275.084 .880 & 278.117 .760 & 626.831 .570 \\
\hline Usposabljanje & 22.560 .000 & 18.720 .000 & / & 41.280 .000 \\
\hline $\begin{array}{l}\text { Varnostna tehnična } \\
\text { oprema }\end{array}$ & 57.189 .360 & 19.535 .040 & / & 76.724 .400 \\
\hline $\begin{array}{l}\text { Informacijska } \\
\text { tehnologija }\end{array}$ & 305.915 .176 & 310.296 .000 & / & 616.211 .176 \\
\hline Skupaj & 536.426 .373 & 693.346 .128 & 278.117 .760 & 1.507 .890 .261 \\
\hline
\end{tabular}

Opomba: v letu 2006 1.160.564 EUR, oziroma skupaj 6.292.314 EUR ${ }^{15}$

Večina načrtovanih nalog se bo predvidoma financirala iz schengenskega vira $v$ skladu z odločitvijo Evropske komisije, davek na dodano vrednost pa se bo financiral iz proračuna.

15 Dopolnitev izvedbenega načrta za uveljavitev schengenskih standardov nadzora zunanje meje EU 2005-07, Vlada RS, Ljubljana, maj 2005, strani 56-57 


\subsection{Pristojnosti Ministrstva za pravosodje}

Vloga Ministrstva za pravosodje pri uvajanju schengenskih standardov je predvsem $v$ pripravi ustreznih predlogov zakonov. Tako je državni zbor v letu 2004 sprejel nov zakon o varstvu osebnih podatkov. Ustanovljen je bil v letu 2005 neodvisni Državni nadzorni organ za varstvo osebnih podatkov ter določene so bile osebe odgovorne za neodvisni nadzor v okviru določb schengenskega sporazuma.

$\checkmark$ tabeli št. 4 so prikazani predvideni dodatni stroški prilagajanja schengenskim standardom Ministrstva za pravosodje:

Tabela št. 4: Ocena predvidenih stroškov v SIT

\begin{tabular}{|lcccc|}
\hline Namen & 2005 & 2006 & 2007 & Skupaj \\
\hline $\begin{array}{l}\text { Plače novo } \\
\text { zaposlenih } \\
\begin{array}{l}\text { Redni materialni } \\
\text { stroški }\end{array}\end{array}$ & 3.000 .000 & 19.800 .000 & 19.800 .000 & 42.600 .000 \\
Investicije & 1.000 .000 & 2.500 .000 & 2.500 .000 & 6.000 .000 \\
\hline Skupaj & 500.000 & 2.000 .000 & 1.000 .000 & 3.500 .000 \\
\hline
\end{tabular}

Oz. 217.409 EUR. ${ }^{16}$

\subsection{Pristojnosti Ministrstva za promet}

Ministrstvo za promet je $v$ procesu izpolnjevanja schengenskih standardov pristojno predvsem za izpolnjevanje standardov na mednarodnih letališčih in mednarodnih pristaniščih.

Republika Slovenija ima tri mednarodna pristanišča in sicer v Kopru, Piranu in Izoli. Ministrstvo za promet oz. Direktorat za pomorstvo in Uprava RS za pomorstvo bosta $\vee$ Kopru strokovno sodelovala pri načrtovanju potniškega terminala ter pri načrtovanju in izvedbi ukrepov za ločitev potnikov na notranjih

16 Dopolnitev izvedbenega načrta za uveljavitev schengenskih standardov nadzora zunanje meje EU 2005-07, Vlada RS, Ljubljana, maj 2005, stran 61 
Janez Mihovec

Uvajanje schengenskih sporazumov in standardov

v Republiki Sloveniji

in zunanjih plovbah. V Izoli in Piranu pa bosta sodelovala pri načrtovanju in izvedbi ukrepov za ločitev potnikov na notranjih in zunanjih plovbah. Poleg tega pa bo pregledana in dopolnjena oz. po potrebi spremenjena Uredba o določitvi pristanišč, ki so namenjena za mednarodni javni promet.

Republika Slovenija ima tudi tri mednarodna letališča in sicer Aerodrome Ljubljana, Maribor in Portorož. Dejavnosti, ki se morajo izvesti na mednarodnih letališčih, so po svoji vsebini enaki kot tisti, ki se morajo izvesti v mednarodnih pristaniščih.

\section{Ocena izpolnjevanja schengenskih sporazumov in schengenskih standardov pri nadzoru Evropske unije}

Priprave za prevzem schengenskih standardov so praktično pri koncu in to potrjujejo tudi komisije, ki v Republiki Sloveniji na terenu kontrolirajo izpolnjevanje pogojev in tudi nudijo tehnično pomoč in pomoč $v$ znanju. Na kopenskih mejah so tako rekoč priprave končane.

Vendar pa obstaja tudi nekaj težav, ki se kažejo v treh osnovnih točkah:

1. Kadrovska problematika - Slovenija se sooča s problemom, kako mejne policiste z meja na severu, zahodu in vzhodu premakniti na nova delovna mesta na južni meji brez prevelikih socialnih problemov za zaposlene in negativnih učinkov na integralni proračun.

2. Problematika mednarodnih pristanišč - na tem področju zamujamo in izgradnja terminalov za ločitev potnikov $v$ skladu s schengenskimi standardi se bo začela šele v letu 2007.

3. Problematika mednarodnih letališč - na tem področju zamujamo in izgradnja terminalov za ločitev potnikov $v$ skladu $s$ mednarodnimi standardi se bo začela šele v letu 2007. ${ }^{\mathbf{7}}$

Republiki Sloveniji so se obrestovala večletna prizadevanja, katerih cilj je bil, da čimprej vstopimo $v$ schengensko območje. Tako angažirana so bila velika sredstva, problematika kopenske zunanje EU meje je bila urejena pravočasno, manjše zamude so le pri letališčih in pristaniščih, vendar pa so glede

17 Zinrajh, Zvonko, Razočarani nad prestavitvijo schengna, Revija Varnost, št. 4, 2006, MNZ strani 13-14. 


\section{Uvajanje schengenskih sporazumov janez Mihovec v Republiki Sloveniji}

na dejstvo, da izredno velik del potniškega prometa poteka prek kopenskih mejnih prehodov, to marginalni problemi, katerih rešitev ne zahteva prevelikih investicij in časovnega trajanja prilagoditev. Slovenija je daleč prehitela preostale novinke $v$ Evropski uniji. Tako so stare članice izrazile dvom nad pripravljenostjo teh držav za vstop in premaknile datum za vstop $\vee$ prihodnost. Uradni razlog za zamik je, da računalniški sistem SIS 2 še ni operativen, neuradni pa dvomljiva pripravljenost držav kandidatk z izjemo Slovenije. Datum za vstop je navkljub temu določen in kot kaže bo Slovenija vstopila $v$ schengensko območje z novim letom 2008.

\section{Zaključek}

Ob širitvi Evropske unije v maju leta 2004 je bilo veliko razmišljanj o Evropi dveh hitrosti. Na eni strani naj bi bile visoke razvite, stare države članice, na drugi strani pa sorazmerno revne novinke iz Srednje in Vzhodne Evrope. Interes Republike Slovenije je bil, da bi čimprej izstopila iz te na neki način drugorazredne skupine. Lahko rečemo, da se je $v$ manj kot treh letih to že $v$ veliki meri posrečilo. Gospodarska rast vsaj dvakrat presega rast povprečja $\vee$ EU, s 85odstotno povprečno razvitostjo Evropske unije je Slovenija prehitela nekatere stare države članice, vstopila je $\vee$ elitni klub uporabnikov druge najmočnejše svetovne valute in na dosegu roke je vstop $v$ schengensko območje.

Janez Mihovec, diplomiral na Visoki poslovni šoli Ekonomske fakultete v Ljubljani, v letu 2006 dokončal specialistični študij na Fakulteti za upravo, v letu 2006-07 vpisan na magistrski program na Fakulteti za upravo. Zaposlen na Ministrstvu za notranje zadeve, Policiji, kot kriminalistični inšpektor na Policijski upravi Ljubljana, Oddelek za gospodarsko kriminaliteto. 
Janez Mihovec

Uvajanje schengenskih sporazumov in standardov

v Republiki Sloveniji

\section{Literatura in viri}

- $\quad$ Burian, D. (1999): Schengen v praksi, MNZ (interno gradivo), str.15-17, 26-28

- Celar, B.(1996): Mednarodno policijsko sodelovanje v luči evropskih integracijskih procesov. MNZ, , str.24-26

- Debelak, S. (2002):. Delovanje uprave pri vzpostavljanju zunanje meje EU. IX. Dnevi slovenske uprave, Visoka upravna šola.

- Debelak, S., Bergelj N.(2002): Migracije in pogoji potovanja v razširjeni Evropi. XI. Dnevi slovenske uprave, Visoka upravna šola, str. 1.

- Dovžan, M.: Uveljavitev Schengenskega sporazuma v slovenskem pravnem redu. Pravna praksa, letnik 2000, številka 35, GV, str. 6.

- Gašperlin, M.: Al prav se piše Schengen ali schedngen. Revija Varnost, MNZ, 2006, št. 4 , str. 14.

- Schengen Visa http://www.eurovisa.info/

- Vlada Republike Slovenije (2001): Izvedbeni načrt za uveljavitev schengenskih standardov nadzora zunanje meje Evropske unije v obdobju 2001-05.

- 11. Vlada Republike Slovenije(2005): Dopolnitev izvedbenega načrta za uveljavitev schengenskih standardov nadzora zunanje meje Evropske unije v obdobju 2005-07.

- Westphal, V., in Stoppa, E. (2004):Evropsko pravo za mejno policijo: praktični učbenik za evropske mejne policiste s področja tujskih, azilnih in begunskih pravnih predpisov Europske unije in Schengenske konvencije, str. 48-49, MNZ, Policija. 


\section{SUMMARY}

\section{IMPLEMENTATION OF SCHENGEN AGREEMENTS AND STANDARDS IN REPUBLIC OF SLOVENIA}

After the end of the second world war cooperation among states in the western Europe increased. Inner borders and administrative procedures became major obstacles to international co-operation. In the years 1984, 1985 and 1990 five European countries signed a line of agreements the so called Schengen concentions, with the objective of abolishing inner borders and creating a homogenous external border of member states. In $1997 / 1999$ the Schengen convetion became part of the Amsterdam treaty and thus part of aquis communitaire of European Union. In the following years additional 10 countries joined Schengen and Europe became the largest area in the world where inner borders had been abolished and a common external border had been created.

Republic of Slovenia became member of European Union in May 2004. This date was not the end of approach to European legislation, it was the beginning of a new era of efforts to becoming a modern and successful state. Being a member of the elite club of nations could bring great benefits to Slovenian economy and also a great responsibility in international society. One of the greatest challenges was the implementation of Schengen agreements and standards.

Already in May 2001, the government of Republic of Slovenia accepted the First executive plan for implementation of Schengen standards for supervision of future external border of European Union. This plan represented the measures which had to be implemented so that Slovenia would be ready to fulfil the obligations of Schengen standards. In May 2005, the Slovenian government accepted the upgraded executive plan (the so-called Second executive plan for implementation of Schengen standards).

Several ministries of Slovenian government have cooperated in preparations for implementation of Schengen standards. The most important roles had Ministry of the Interior, Ministry of Public Administration, Ministry of Foreign Affairs, Ministry of Justice and Ministry of Transport and Communications. The most important role in implementation of 
Janez Mihovec

Uvajanje schengenskih sporazumov in standardov

v Republiki Sloveniji

Schengen standards has had Ministry of the Interior, in particular the Police.

Many decisions have been taken relating to the organisation of Slovenian Police, of which the most important are:

- The organisation of the Police shall remain uniform, there will be no special border police

- Autonomy is foreseen for Police units for border control

- Experience of German and Austrian police will be applied in the new organisation

- For implementation of Schengen standards the Slovenian police will be organised on three levels: local, regional and state level

- Because of numerous new tasks several new policemen will be employed

- The support of technicians and computer experts in the Slovenian police will be extended.

The executive plan for implementation of Schengen standards foresees 3092 policemen for execution of Schengen agreements. 2810 policemen will be employed on local level, the rest on regional and state levels.

Additional workers, technical equipment and objects will bring about additional costs. It is estimated that the total costs of preparation will be 202,6 million EUR and annual cost of implementation of Schengen standards will be additional 74 million EUR. Most of the costs are wages 38,5 $\%$ and investments $53,2 \%$ of total amount. About $45 \%$ of the means are provided from EU funds, the rest from the budget of Republic of Slovenia.

After almost a decade of preparation for implementation of Schengen agreements and Schengen standards it seems that the final goal for Slovenia is within reach. After some delays it seems that the leaders of European Union reached agreement that new member states will implement the Schengen agreements into full execution on 1st December 2007, under condition that they fulfil all the obligations of Schengen standars.

Slovenia seems to be well prepared. Evaluation groups which control and support the preparation share this opinion. Only three issues remain to be solved, relating to: 
- Personnel - a large number of persons, policemen will be transferred from north, west and east border to southern border with Croatia which will cause some additional cost and social problems.

- International seaports - on this area there are delays; investments to terminals for separate entrance of passengers will be needed.

- International airports - applies the same as for international seaports.

However, those issues do not seem to be major obstacles or will they need major investments.

In May 2004, when Slovenia entered the European Union, there was much discussion about Europe of two velocities. It seemed then that states which had not implemented common currency EUR and states which had not been included in Schengen agreement, among them also Slovenia, were a kind of second class states. Now, Slovenia has already overcome the first obstacle and the second objective is within reach. 